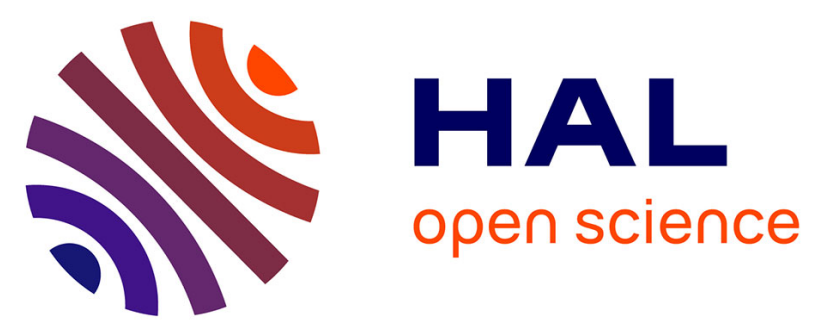

\title{
Geodynamic evolution of the northeast Japan continental margins during Cenozoic times : new insights
}

\author{
Serge Lallemand, Jean Paul Cadet, Laurent Jolivet
}

\section{To cite this version:}

Serge Lallemand, Jean Paul Cadet, Laurent Jolivet. Geodynamic evolution of the northeast Japan continental margins during Cenozoic times : new insights. Bulletin de la Société Géologique de France, 1987, 8 (3), pp.499-509. hal-03273433

\section{HAL Id: hal-03273433 \\ https://hal.science/hal-03273433}

Submitted on 29 Jun 2021

HAL is a multi-disciplinary open access archive for the deposit and dissemination of scientific research documents, whether they are published or not. The documents may come from teaching and research institutions in France or abroad, or from public or private research centers.
L'archive ouverte pluridisciplinaire HAL, est destinée au dépôt et à la diffusion de documents scientifiques de niveau recherche, publiés ou non, émanant des établissements d'enseignement et de recherche français ou étrangers, des laboratoires publics ou privés. 


\title{
Geodynamic evolution of the northeast Japan continental margins during Cenozoic times : new insights
}

\author{
by Serge LALlemand *, Jean-Paul CADET ** and Laurent JOLIVET *
}

Key words. - Geodynamic, Continental margins, Plates, Subduction, Obduction, Compressive stress regime, NE Japan.

\begin{abstract}
We attempt to clarify and compare the tectonic behaviours of the NE Japan margins during Cenozoic, with special reference to the Amur - Okhotsk plate boundary.

According to the authors analysis and previous studies, we consider the following sketches between east and west margins of NE Japan. 1) The formation of the rifted eastern margin of Japan Sea occurred during Eocene-Oligocene along a N-S right-lateral shear zone which extended northward through the Tartary gulf. At that time, subduction of the paleo-Pacific plate was not very active or even ceased and the forearc uplifted giving rise to the Oyashio landmass. 2) The opening of the Japan Basin as a mega-pull-apart between two large N-S right-lateral shear zones occurred during late Oligocene-early Miocene owing to the motion of the North America plate relative to Eurasia. Thus, the tectogenesis of the eastern margin of the Japan Sea as a strike-slip margin with small en-echelon pull-aparts occurred from Eocene to early Miocene. Subduction started again on the western side of this new island arc from late Oligocene and the emerged forearc began to subside. The Japan trench axis was located at least $200 \mathrm{~km}$ eastward of its present position. 3) The Yamato and Tsushima basins as well as many smaller ones inside the Korean Plateau or the eastern margin of the Japan Sea opened during middle Miocene related to the subduction of the Pacific plate under NE Japan simultaneously with the erosion of the front of the forearc and westward retreat of the trench. 4) Since $2 \mathrm{Ma}$, the forearc shows an uplift well correlated with the closing initiation of the Japan Sea along its eastern margin due to the rejuvenation of the ancient normal faults into reverse ones (ESTASE I cruise results). Major shallow earthquakes occurring in the back-arc clearly determine a convergent zone running along the entire margin and it is likely that this deformation better represents the present plate boundary between the Amur and Okhotsk plates than the central Hokkaido tectonic belt. The gravity sliding which affects the frontal zone of at least the northern Japan trench (KAIKO cruise results), is induced by the motions of oceanic faults below the edge of the continental wedge and does not reflect the general tectonic regime of the arc. Most of the data are consistent with a major influence of the Pacific plate subduction on the NE Japan arc tectonic regime at present.
\end{abstract}

\section{L'évolution géodynamique des marges continentales du Japon nord-oriental au cours du Cénozoïque : une nouvelle interprétation}

Résumé. - Cette étude tente de clarifier et de comparer le comportement géodynamique des marges du Japon nord-oriental entre elles, du Cénozoïque à l'Actuel, à la lumière des nouveaux travaux issus entre autres des campagnes à la mer : KAIKO et ESTASE I.

Le calendrier tectonique concernant l'évolution de l'avant et de l'arrière-arc du Japon nord-oriental, que nous retenons, est le suivant. 1) La marge est de l'actuelle mer du Japon prit naissance à l'Éo-Oligocène le long d'une zone de cisaillement dextre méridienne se prolongeant ver's le Nord à travers le détroit des Tartares. A cette époque, la subduction de la paléo-plaque Pacifique n'était pas aussi active qu'actuellement à en juger par l'absence de volcanisme du Paléocène à l'Oligocène inférieur. L'avant-arc se souleva jusqu'à l'émersion d'une île, à présent enfouie sous $3000 \mathrm{~m}$ d'eau et de sédiments, baptisée Oyashio. 2) L'ouverture du bassin du Japon (bassin principal de la mer du Japon) en méga-pull-apart entre deux grandes zones de cisaillement dextres sub-méridiennes eut lieu à l'Oligocène supérieur-Miocène inférieur comme la conséquence du mouvement relatif entre les plaques Amérique du nord et Eurasie. Autrement dit, la tectogenèse de la marge est de la mer du Japon en marge décrochante flanquée de petits pull-aparts en-échelon dura de l'Éocène au Miocène inférieur. La subduction reprit sous la marge opposée de ce nouvel arc insulaire et la paléo-île d'Oyashio commença à subsider. A cette époque, l'axe de la fosse du Japon se trouvait $200 \mathrm{~km}$ plus à l'Est qu'actuellement. 3) Les bassins secondaires de Yamato, Tsushima ainsi que de nombreux autres plus réduits dans le plateau coréen ou la marge orientale de la mer du Japon s'ouvrirent au Miocène moyen. Il s'agit cette fois-ci d'ouvertures arrière-arc liées à la subduction de la plaque Pacifique sous le Japon nord-oriental. Le rebord de l'avant-ar'c se consuma en réponse au retrait vers le continent de la fosse du Japon d'au moins 200 km. 4) Depuis $2 \mathrm{Ma}$, l'avant-arc se soulève en même temps que la mer du Japon commence à se fermer le long de sa bordure orientale grâce notamment au rejeu inverse des anciennes faillès normales orientées sensiblement N-S (résultat de la campagne ESTASE I). Les principaux séismes superficiels arrière-arc déterminent clairement une zone convergente le long de la marge orientale de la mer du Japon. Cette marge intensément déformée correspond vraisemblablement à la frontière actuelle entre les plaques Amur et Okhotsk, plutôt que le long de la chaîne centrale d'Hokkaido. Notons que les glissements en masse se produisant au front de la zone de subduction, au moins dans la partie nord de la fosse du Japon (résultat des campagnes KAIKO) ne reflètent en rien le régime tectonique général de l'arc ; ils sont simplement dus au jeu des failles océaniques sous le mur interne de la fosse. La plupart des données semblent indiquer une influence majeure de la subduction de la plaque Pacifique sur le régime de contraintes actuel dans l'arc, au sens large, du Japon nord-oriental.

* Lab. Géologie, École Normale Supérieure, 24, rue Lhomond, 75231 Paris cedex 05.

** Lab. Géodynamique, Dép. Sciences de la Terre, Univ. Orléans, 45046 Orléans cedex. Present address : Lab. Tectonique, UPMC, 4, pl. Jussieu, 75252 Paris cedex 05.

Note présentée à la séance du 25 novembre 1985, déposée le 27 janvier 1986 ; manuscrit définitif accepté le 25 septembre 1986. 


\section{I. - INTRODUCTION.}

The aim of this study is to compare the geodynamic evolution of the NE Japan continental margins during Cenozoic times in order to clarify what is related to the subduction of the Pacific plate and what can be attributed to the relative motion of the other surrounding plates.

The island arc of Japan is located : - at the junction of at least four plates (fig. 1) ; - above two contortioned subducting slabs and - at the edge of the Asian mainland.

The problem is to estimate the role of each factor in the tectonics of the arc. The influence of the subducting Pacific plate, for example, is a function of the subduction rate, the dip of the slab, the convergent angle between the plates [i.e. Takeuchi, 1983] and the shape of the slab especially at trench corners. Forearc tectonics are obviously mostly related to subduction, to what extent this applies to back-arc basin is difficult to ascotain. In the same way, strike-slip tectonics are likely at the border of continents as was the case in East Asia during Cretaceous times, with the activity of major left-lateral faults like the central Sikhote-Alin fault or the Tanakura fault (fig. 1) [Otsuki and Ehiro, 1978].

New data obtained during the Leg 3 of the frenchjapanese KAIKO cruise [Cadet et al., 1985, 1987] and during the ESTASE 1 cruise [Lallemand et al., 1985] in 1984 onboard $\mathrm{R} / \mathrm{V}$ Jean Charcot on one hand and recent field survey in Hokkaido on the other allow us to propose new ideas on recent tectonics, especially for the eastern margin of the Japan Sea and for the base of the northern Japan trench lower slope. Taking, also, into account previous studies, a comparative tectonic evolution scheme of both margins is proposed.

II. - Structural eVolution of the NE JAPAN AND its Margins Since Cretaceous.

During the Upper Cretaceous, the Japanese islands were still part of the Asian continent and belonged to the OkhotskChukotka volcanic belt [Takahashi, 1983]. This active margin underwent a strong shearing along NE-SW left-lateral strike-slip faults [Otsuki and Ehiro, 1978].

1) Pull-apart opening of the Japan Sea in Oligo-Miocene times.

We proposed recently [Lallemand and Jolivet, 1986] that the opening of the Japan Basin was induced by the rightlateral motion of the paleo North-America plate (East of the Hidaka shear zone, fig. 1) relative to the paleo Eurasia plate (west of the Hidaka shear zone, fig. 1) during Paleogene and Lower Miocene. Then, the opening of the Yamato and Tsushima basins occurred as back-arc spreading related to the subduction of the Pacific and Kula (PAC) or protoPhilippine Sea plates (PH.S).

Figure 2 illustrates the two main stages of opening. After an Eo-Oligocene rifting of a pull-apart basin accomodated along two large right-lateral shear zones as defined by Lallemand and Jolivet [1986], one east of Korea and the other west of NE Japan and Sakhalin (fig. 2-1), the main opening of the Japan Basin began during late Oligocene-

Bull. Soc. géol. Fr., 1987, $\mathrm{n}^{\circ} 3$

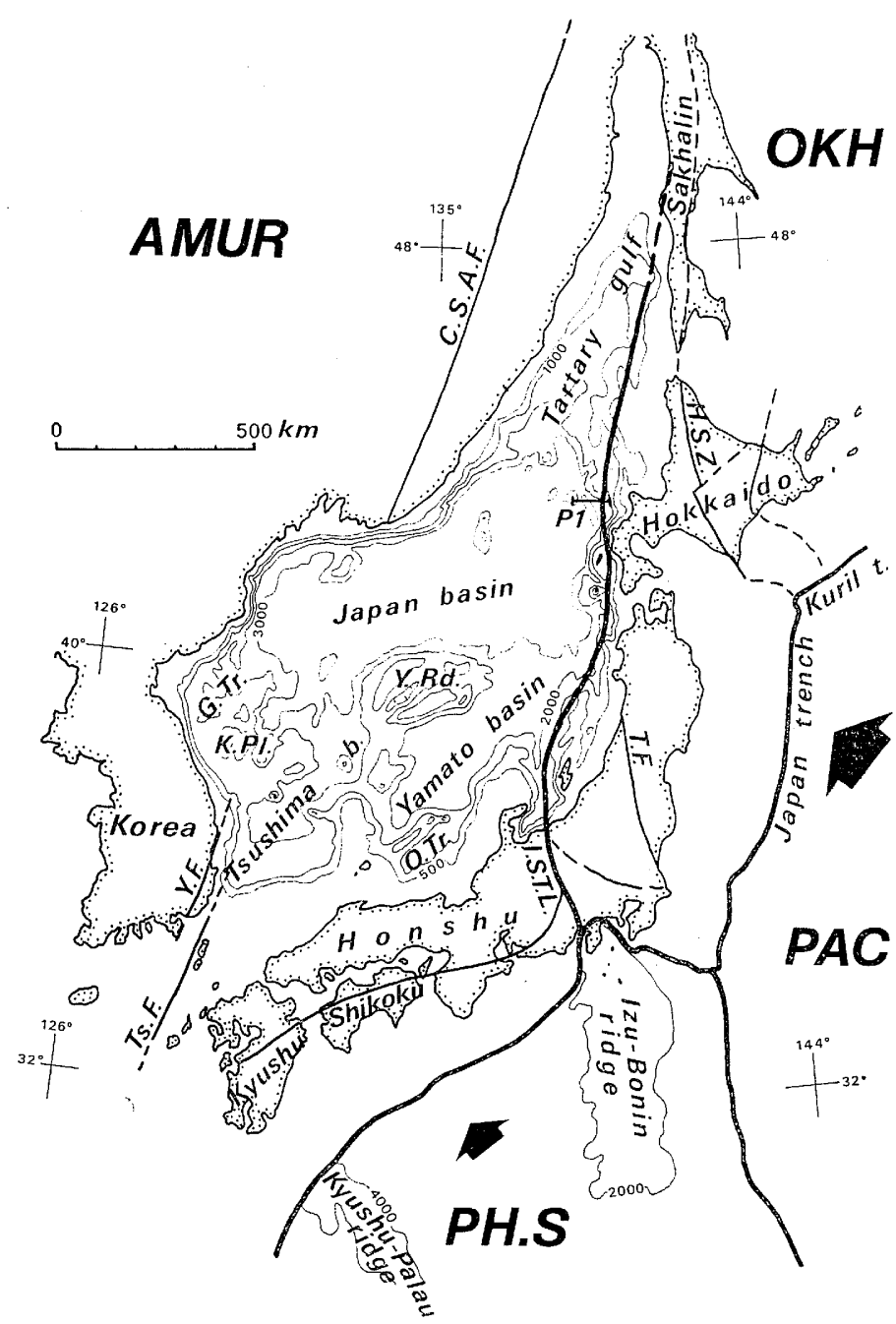

FIG. 1. - Structural context and physiography around the Japanese islands. Thick lines represent the assumed plate boundaries.

OKH : Okhotsk plate ; PH.S : Philippine Sea plate ; PAC : Pacific plate; ISTL : Itoigawa-Shizuoka tectonic line ; HSZ : Hidaka shear zone; CSAF : Central Sikhote Alin fault; YF : Yangsan fault ; Ts. F : Tsushima fault ; T.F : Tanakura fault ; Y. Rd : Yamato ridge ; K. Pl : Korean Plateau; G. Tr : Genzan Trough; O. Tr : Genzan Trough ; O. Tr : Oki Trough.

FIG. 1. - Grandes lignes tectoniques et physiagraphie de la région des iles japonaises. Les traits gras représentent les frontières de plaques présumées.

$\mathrm{OKH}$ : plaque Okhotsk; PH. S : plaque de la mer des Philippines ; PAC : plaque Pacifique ; ISTL : ligne tectonique d'Itoigawa-Shizuoka; HSZ : zone de cisaillement d'Hidaka ; CSAF : faille centrale de Sikhote Alin ; YF : faille de Yangsan; Ts. F : faille de Tsushima; T. F : faille de Tanakura; $\mathrm{Y} . \mathrm{Rd}$ : ride de Yamato ; $\mathrm{O} . \mathrm{Rd}$ : ride d'Oki ; $\mathrm{K} . \mathrm{PI}$ : plateau coréen; G. $\mathrm{Tr}$ : dépression de Genzan; O. Tr : dépression d'Oki.

early Miocene (fig. 2-2). Then, the Yamato, Tsushima and other smaller basins on the Korean and Japanese margins (such as the Genzan trough and Oki trough in figure 1) opened at the end of Lower Miocene and during Middle Miocene [Lallemand and Jolivet, 1986] (fig. 2-3). This model is in good agreement with the compiled and newly obtained palaeomagnetic data obtained by Lee et al. [1987]. 


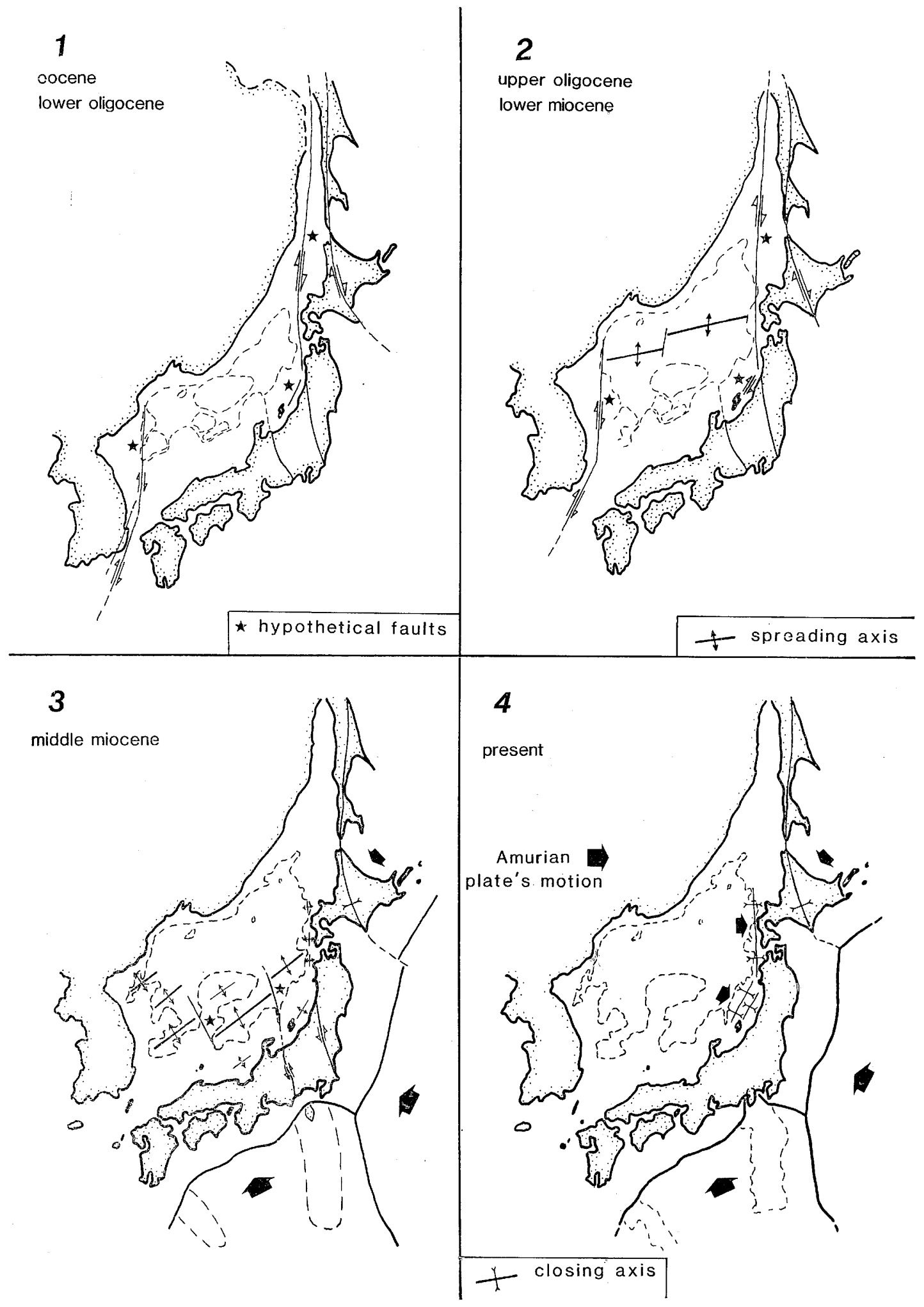

FIG. 2. - Reconstruction of the circum Japan Sea region from Eocene to Present according to Lallemand and Jolivet [1986]. Fig. 2. - Différentes étapes de l'ouverture de la mer du Japon de l'Eocène jusqu'à l'Actuel d'après Lallemand et Jolivet [1986]. 


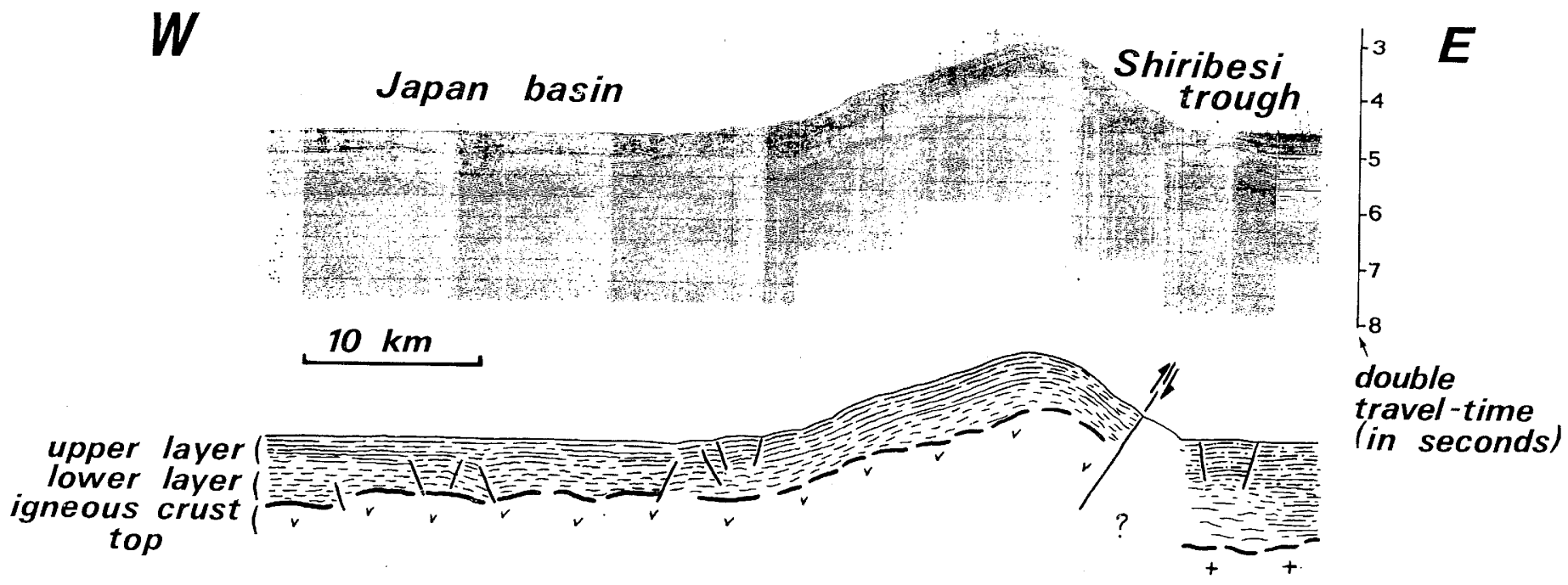

FIG. 3. - Interpretation of seismic profiles P 1 (see location on fig. 1).

FIG. 3. - Interprétation des profils sismiques P 1 (voir localisation fig. 1).

2) Quaternary compressive tectonics along the eastern margin of the Japan Sea.

This margin underwent strong E-W compressive deformations since 1 or $2 \mathrm{Ma}$ (fig. 2-4) [Fukao and Furumoto, 1975 ; Nakamura and Uyeda, 1980]. According to Nakamura [1983, 1984] and other authors [Kobayashi, 1984 ; Seno, 1983], it could correspond to a new convergent plate boundary between the North America and Eurasia plates (the Okhotsk and Amurian plates on figure 1). Their evidence (earthquakes, seismic profiles, discontinuity in $\mathrm{P}$ waves velocities) favours a nascent trench at the base of the margin where the Japan Basin begins to subduct eastward under the margin. Five seismic profiles were recorded during the ESTASE 1 cruise (chief scientist : L. Labeyrie), crossing the assumed nascent trench in order to test this hypothesis [Lallemand et al., 1985]. No conclusive evidence was found to support the nascent trench hypothesis, however many features indicated E-W compression along this margin, the compression accomodated on east and west dipping N-S reverse faults [Tamaki and Honza, 1985]. Figure 3 shows an example of eastward thrusting (deduced from regional considerations) of the Japan Basin on the fringing ridges of the continental margin [Lallemand et al., 1985; Okada et al., 1985].

Active faults exist also on land and follow approximately the same strike as on the eastern margin of Japan Sea. Most of them are reverse-type [Research Group for Active Faults, 1980] and seem to be rejuvenated pre-existing faults [Otsuki et al., 1979]. Fault analysis in the southeastern part of NE Japan [Otsuki et al., 1979] and focal mechanisms of shallow earthquakes [i.e. Hasegawa et al., 1983] permit the determination of the Quaternary tectonic stress field in NE Japan. It is characterized by an horizontal maximum principal stress axis with a N125E strike parallel to the direction of convergence between the Pacific plate and the Japanese continental margin.

Bull. Soc. géol. Fr., 1987, no 3

\section{3) Tectonic relations with the Japan trench forearc.}

An E-W cross-section of NE Japan [Ishiwada et al., 1977] (fig. 4) shows clearly the contrast between the east and west Japanese margins.

Based on the results of DSDP Legs 56 and 57 (see the locations of holes on figure 5) [Von Huene et al., 1982], we can summarize as follows the Cenozoic history of the northern Japan trench forearc. Subduction off NE Japan occurred during Cretaceous to early Paleogene and might have been responsible for perhaps through repartition in an accretionary complex the great thickness $( \pm 45 \mathrm{~km} !)$ of the landward dipping Cretaceous sequence. Late Paleogene time was characterized by subaerial erosion of the Oyashio landmass caused by the emergence of the " accretionary complex ». The absence of Eocene to early Oligocene volcanism seems to show that no subduction occurred during this period. At the end of the Paleogene, this paleolandmass began to subside simultaneously with the reactivation of subduction and associated volcanism. Neogene sedimentary cover overlies unconformably the previous complex and records, through the benthic foraminiferal assemblages, the subsidence. This last period of convergence does not show obvious accretion but, instead, it is marked by erosion at the front of the margin and the retreat of the overriding plate by at least $200 \mathrm{~km}$.

Figure 4 gives an idea of the change of the basement depth from Miocene across the island arc [Sugi et al., 1983] deduced from palaeontologic and lithologic characteristics. It appears that the opening of the Japan Sea from late Oligocene to middle Miocene can be correlated with the subsidence of the forearc and the Quaternary compressive regime well expressed along the eastern margin of the Japan Sea coincides with the recent uplift of the forearc. It seems, therefore, that the tectonic regime across the island arc is governed by the same phenomenon, i.e. the coincidence of crustal movements on each side of the arc, but the effect 

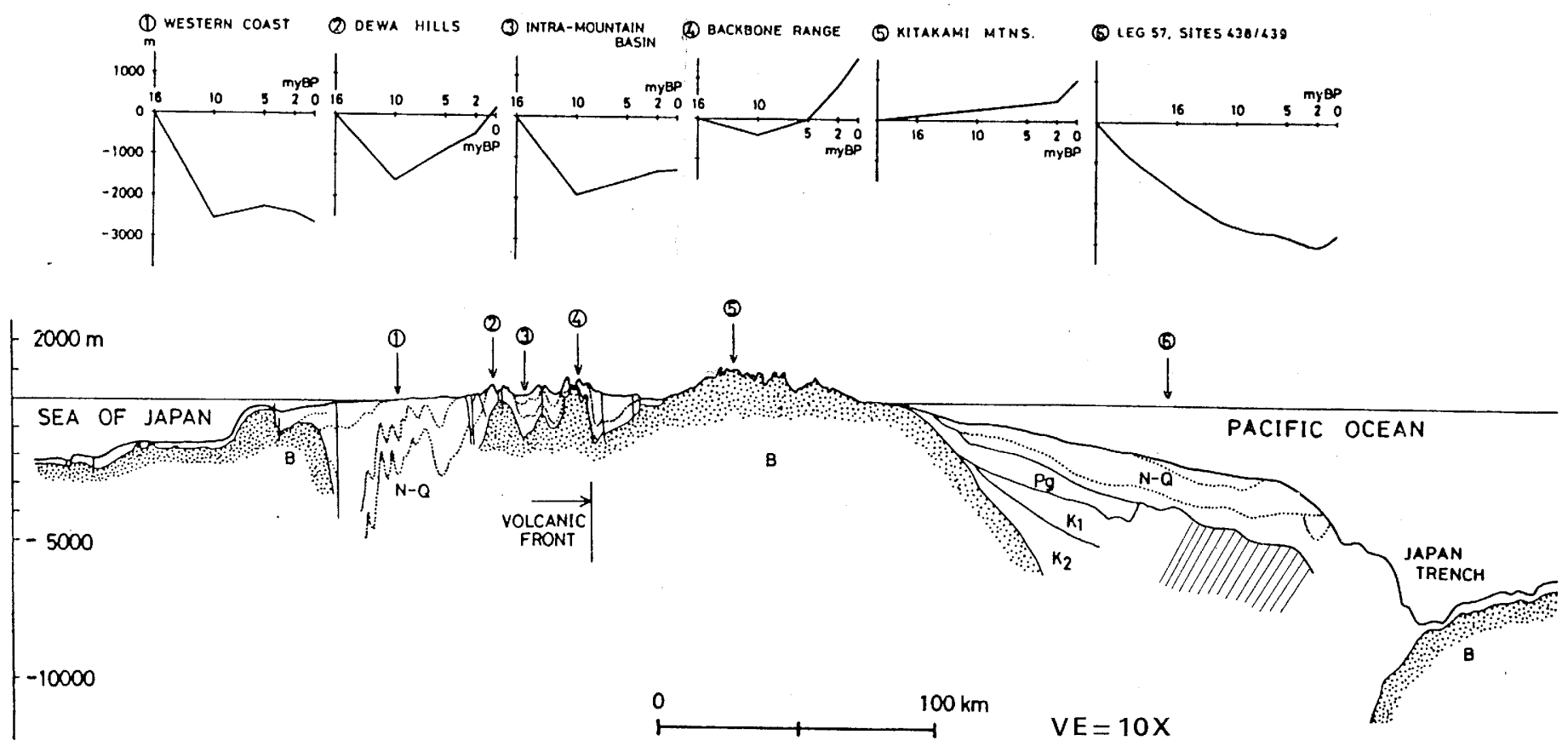

FIG. 4. - East-West cross-section of northeast Japan along latitude $39^{\circ} 30^{\prime} \mathrm{N}$ adapted from Ishiwada et al. [1977] and the change of the basement depth determined by Sugi et al. [1983] on land and at the forearc region (DSDP, sites 438/439, see fig. 5).

N-Q : Neogene-Quaternary sediments ; PG : Paleogene ; K1 : Upper Cretaceous system ; K2 : Lower Cretaceous system ; B : basement rocks : pre-Cretaceous and granitic rocks.

FIG. 4. - Coupe Est-Ouest du Japon NE suivant la latitude de 39³0' $N$ d'après Ishiwada et al. [1977] et les variations de profondeur du socle déterminées par Sugi et al. [1983] à terre et sur l'avant-arc (DSDP, sites 438/439).

$\mathrm{N}-\mathrm{Q}$ : sédiments néogènes et quaternaires ; $\mathrm{PG}:$ Paléogène ; $\mathrm{K} 1$ : ensemble crétacé supérieur ; $\mathrm{K} 2$ : enisemble crétacé inférieur ; $\mathrm{B}$ : socle : roches granitiques et anté-Crétacé.

is amplified in the back-arc basin or at the boundary between the back-arc and the arc causing intense Plio-Quaternary folding and the reactivation of Miocene normal faults into reverse ones [Lallemand et al., 1985]. In contrast, the Neogene-Quaternary sedimentary cover of the forearc is only slightly folded. According to Takeuchi [1983] and others, variations of the different parameters of the Pacific plate subduction, like the angle of convergence between both plates and the inclination of the downgoing slab, are the only factors which are responsible for the tectonic stresses within the island arc system including the Japan Sea margin. Alternatively, it may be due to the occurrence of a zone of weakness inside the margin created at the time of the opening of the Japan Basin.

FIG. 5. - Location of the Kaïko survey (leg 3, box 1) off northeast Japan in addition to the previous multichannel seismic lines. DSDP sites (legs 56-57 and 87) were also plotted on this map. Isobaths are derived from the bathymetric chart of the adjacent seas of Nippon $\mathrm{n}^{\circ} 6301$ [Hydrographic Department, Maritime Safety Agency, Japan, 1966].

FIG. 5, - Localisation de la zone étudiée pendant la campagne Kaiko (leg 3, boite 1) au large du Japon NE ainsi que des lignes sismiques multitraces réalisées auparavant. Les sites de forage DSDP (legs 56-57 et 87) sont figurés. Les isobathes ont été dessinées à partir de la carte bathymétrique des « Mers environnant le Japon» $n^{\circ} 6301$ [Hydrographic Department, Maritime Safety Agency, Japon, 1966].

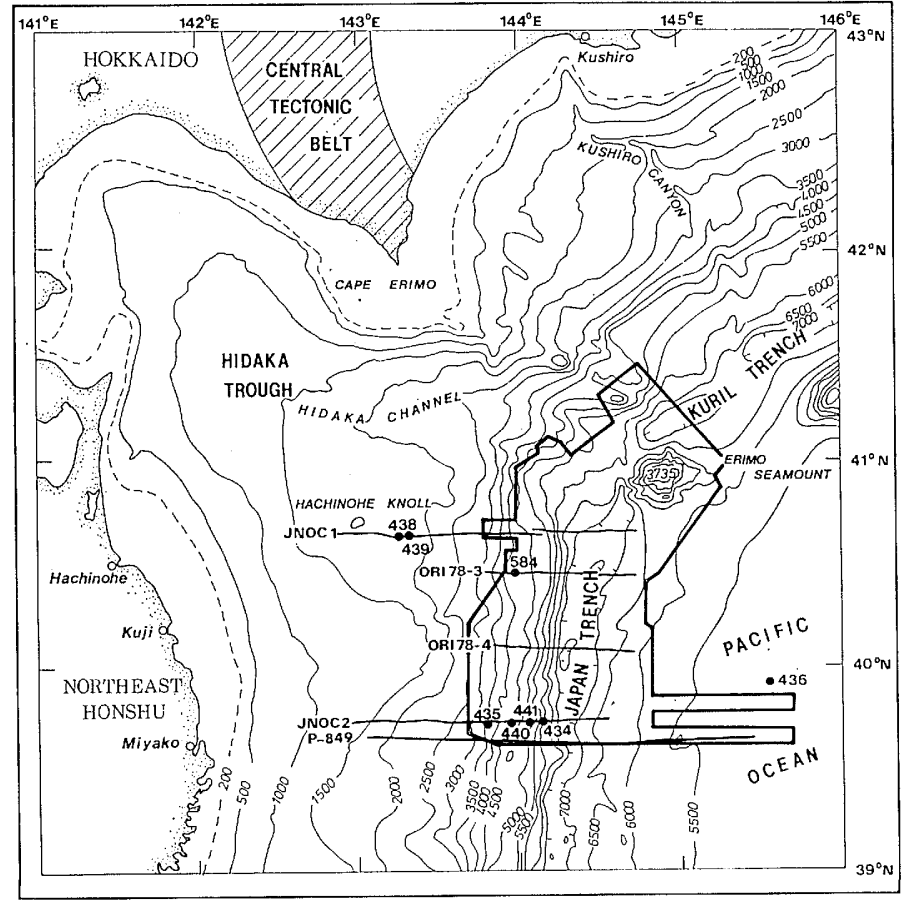

Bull. Soc. géol. Fr., 1987, nº 3 


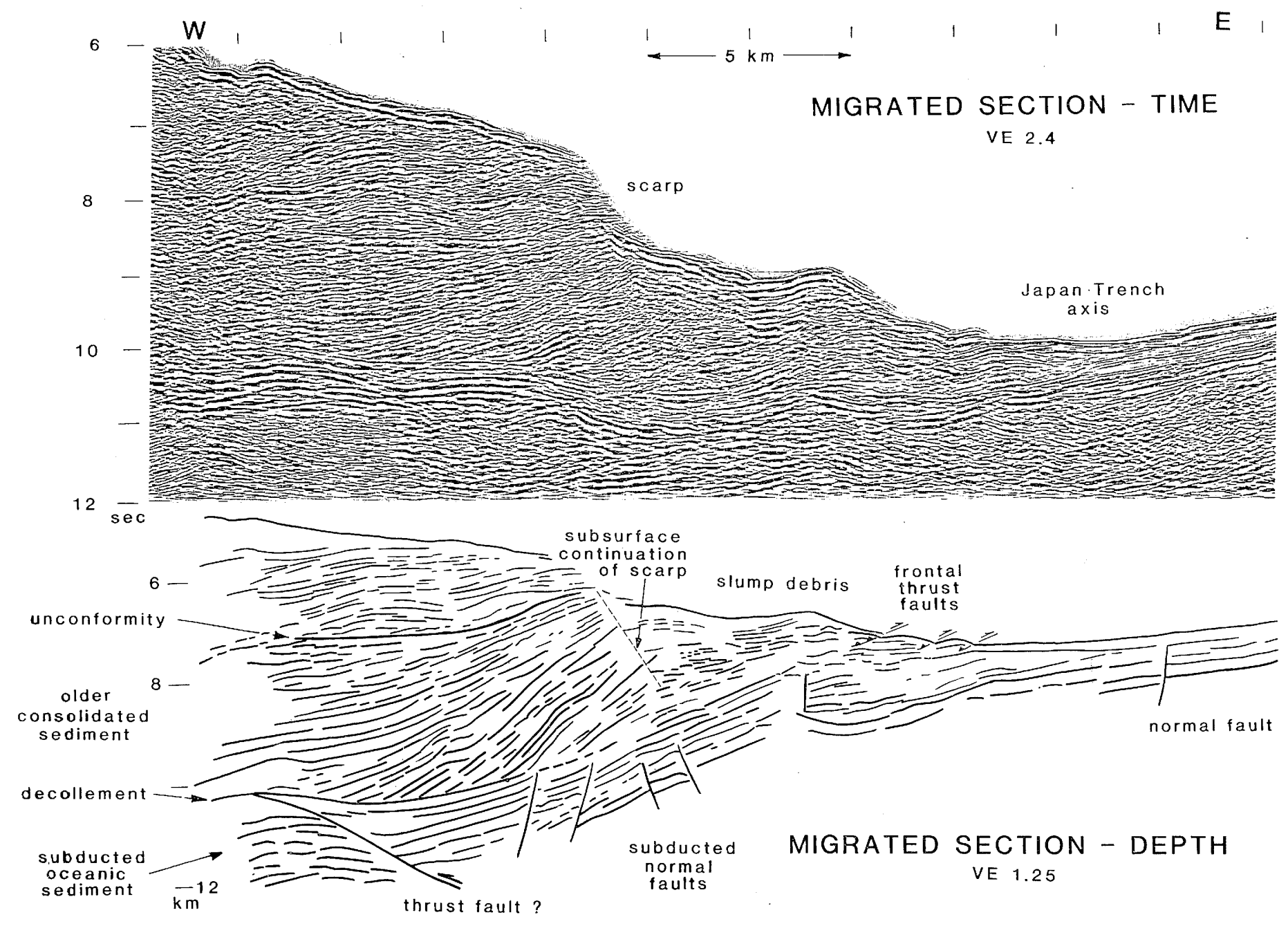

FIG. 6. - Reprocessed seismic record section ORI 78-4 after Von Huene [1986]. Location on figure 5.

FIG. 6. - Section du profil sismique retraité ORI 78-4 d'après Von Huene [1986]. Localisation sur la figure 5.

III. - NeW INSIGHTS ABOUT TECTONIC EROSION AT THE FRONT OF THE NORTHERN JAPAN TRENCH LANDWARD SLOPE INFERRED FROM KAIKO RESULTS.

An excellent seismic profile crossing the northern Japan trench (ORI 78-4, see figure 6 for location) and reprocessed by Von Huene (fig. 6) [Von Huene, 1986] indicates that the oceanic sedimentary cover descends, without obvious accretion, down the subduction zone probably with additional sediments supplied from the inner wall. It is also possible to follow the horst and graben oceanic structure below the edge of the margin. The front of the margin is composed of a thick sequence of, probably Cretaceous or Paleogene strata of which reflectors are cut at the contact with the oceanic plate. It indicates that abrasion by the oceanic subducting crust occurs below the margin. A Neogene sedimentary cover unconformably overlies the older consolidated sediments which outcrops at a huge slump scar. The toe, located between this scarp and the trench axis, is mostly composed of slump debris supplied by the inner wall in association with listric faults [Lehner et al., 1983]. The absence of thick trench fill sedi- ments seems to indicate that slump debris are subducted rapidly. This is probably a second erosional factor responsible for the progressive retreat of the margin. A simple calculation shows that a $400 \mathrm{~m}$ thick trench fill, continuously subducted at a constant rate of $8 \mathrm{~cm} / \mathrm{year}$, is sufficiant to explain the $200 \mathrm{~km}$ retreat of the Japan trench since early Miocene. This distance is deduced from the occurrence of dacite boulders at site 439, dated radiometrically $23.4 \pm$ 5.5 Ma by Moore and Fujioka [1980]. The problem then, is to know which mechanism induced the gravity slidings down to the trench axis. This area was surveyed in detail during the french-japanese KAIKO cruise (see figure 5 for location), which provided accurate seabeam maps, closely spaced single channel seismic profiles, gravity and magnetic maps [Cadet et al., 1985, 1987]. These data combined with focal mechanisms of earthquakes occurring either in the subducting or the overriding plate lead us to say that the intermittent fault motion of the $N 65^{\circ} \mathrm{E}$ (parallel to the magnetic lineations) and N-S (parallel to the trench axis) oceanic faults continues under the continental margin and induces, from time to time, major block movements of the front of the margin [Lallemand et al., 1986].

Bull. Soc. géol. Fr., 1987, $\mathrm{n}^{\circ} 3$ 


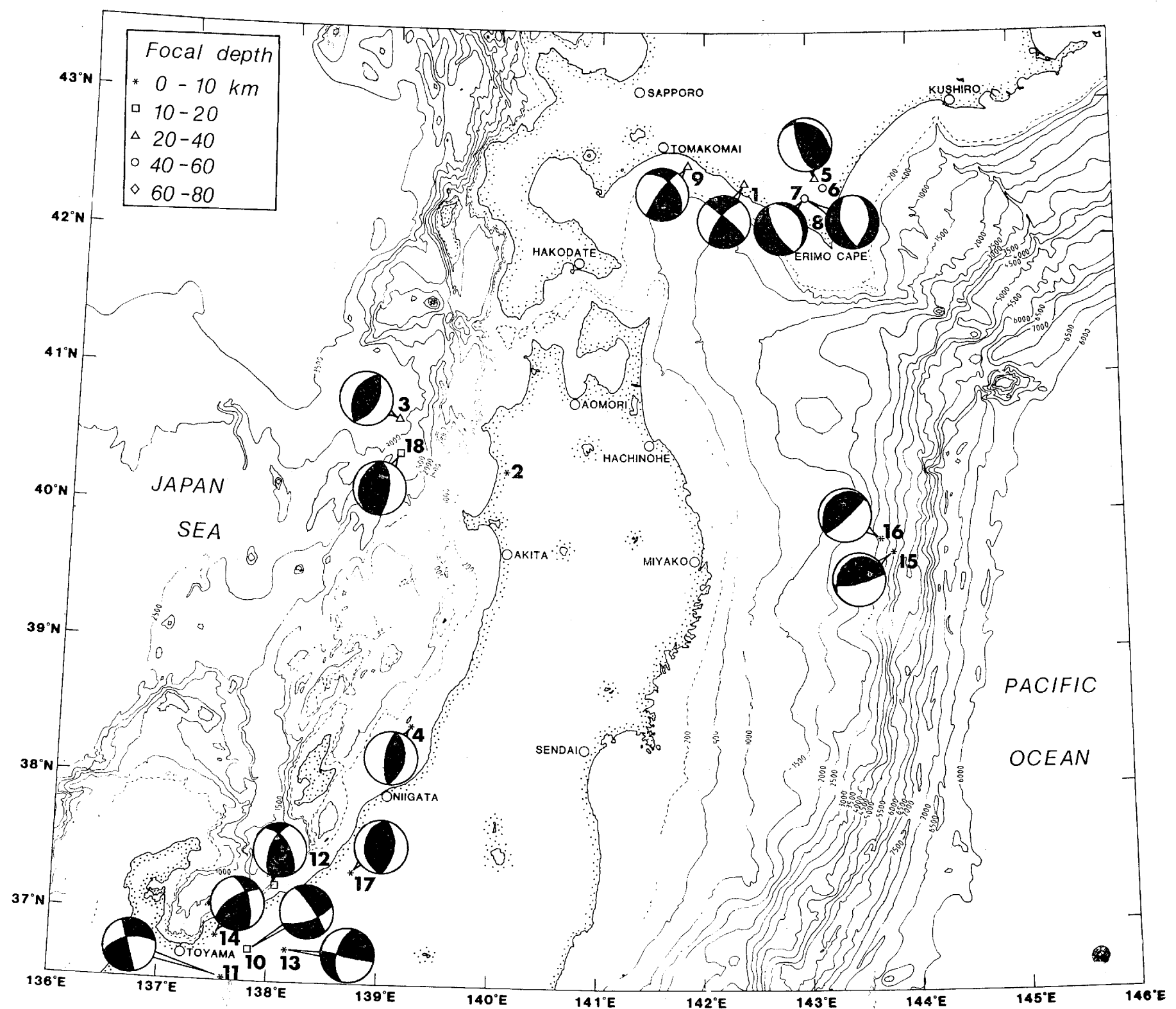

FIG. 7. - Focal mechanisms of some earthquakes which occurred inside the upper plate from 1932 to 1983. See table I for more details.

Fig. 7. - Mécanismes au foyer de quelques séismes ayant eu lieu au sein de la plaque supérieure de 1932 à 1983. Voir tableau I pour plus de détails.

IV. - Present tectonic STRESS IN NE JAPAN AND THE PROBLEM OF THE AMUR-OKHOTSK PLATE BOUNDARY.

Based on a study of dike swarms, faults and earthquakes data, the trajectories of the maximum horizontal tectonic stress have been compiled by Nakamura and Uyeda [1980] especially in the NE Japan. They found WNW-ESE extension from 21 to $7 \mathrm{Ma}$ BP (27 to $7 \mathrm{Ma}$ for Takeuchi [1983]) and WNW-ESE compression since $6 \mathrm{Ma}$. The analysis of seismic profiles recorded across the eastern margin of the Japan Sea indicates that the thrust activity began only 1 or $2 \mathrm{Ma}$ ago [Lallemand et al., 1985 ; Tamaki and Honza, 1985]. DSDP results in the forearc area also indicate a major change from subsidence to uplift since 1 or $2 \mathrm{Ma}$ [Von Huene et al., 1982].

Major earthquakes which occurred inside the upper plate in NE Japan during this century together with their focal mechanisms are shown in figure 7 and listed on table I. Interpretations in terms of fault planes are represented in figure 8. The reverse faults along the eastern margin of the Japan Sea deduced by seismic profiles analyses and earthquakes analyses [see references on table I] determine an active convergent zone with a WNW-ESE direction of some tens of kilometers wide. It could be a nascent plate boundary between the Amurian plate and the Okhotsk plate [i.e. Nakamura, 1983 ; Seno, 1985] rather than that 
proposed along the Hokkaido central tectonic belt extending southeastward to the Japan and Kuril trench junction [Chapman and Solomon, 1976]. There are several reasons to support this : it appears that the eastern margin of the Japan Sea is characterized by intense N-S axes folding [Mizoue et al., 1982; Mogi, 1981] and active faults [The Research Group for Active Faults of Japan, 1980]. Focal mechanisms of earthquakes all along this margin are also quite consistent with a WNW-ESE compression. Further, only the Pliocene sediments lying west of the central tectonic belt record compressive stress, whereas Quaternary sediments are not affected [Mitani, 1978]. And major earthquakes occurring inside the upper plate are distributed in a small zone south and southwest of the central tectonic belt. The possible plate boundary on the Japan Sea side can conveniently be extended southward in a strike-slip boundary along the Itoigawa-Shizuoka tectonic line [Nakamura, 1983 ; Seno, 1985]. Another contradiction at the central Hokkaido plate boundary is the great variety of earthquake focal mechanisms; these are sometimes consistent with a NE-SW compression along NW-SE reverse faults (earthquake $\mathrm{n}^{\circ} 5$ and 6 on figure 7 and 8) and sometimes with a ENE-WSW extension along NNW-SSE normal faults

\begin{tabular}{|c|c|c|c|c|c|c|c|c|c|c|c|c|}
\hline $\mathrm{N}^{*}$ & Date-Time & M. & Lattitude & Longitude & Oeppth & F-Strike & $F-L g$ & $F-w_{0}$ & F-Oip & $\mid F-0-51$ & Faulting-type & References \\
\hline 1 & 26 nor. 1932 & $?$ & $42.26^{\circ} \mathrm{N}$ & $142^{\circ} 24^{\circ} \mathrm{E}$ & 40 & $N W-S E$ & & & & & $\begin{array}{l}\text { Lefr-lateral } \\
\text { strike-slip }\end{array}$ & $\begin{array}{l}\text { ICHIKAWA, } \\
\text { TAKANAMI, } \\
1977 \\
\end{array}$ \\
\hline 2 & 19 oct. 1955 & 5.7 & $40^{\circ} 18^{\circ} \mathrm{N}$ & $140^{\circ} 12^{\prime} \mathrm{E}$ & $0.2 *$ & $\mathrm{~N}-\mathrm{S}$ & 15 & 4 & $64^{\circ}$ & 20.5 & Reverse & MIZOUE et at. , 1982 \\
\hline 3 & 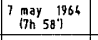 & 6.9 & $40^{\circ} 39^{\prime} \mathrm{N}$ & $139^{\circ} 05^{\prime} \mathrm{E}$ & 22 & NNE-SSW & 50 & 20 & $45^{\circ}$ & 120 & Reverse & $\begin{array}{c}\text { FUKAO and FURUMOTO, } \\
\text { 1975. }\end{array}$ \\
\hline 4 & 16 Jun. 1966 & 7.5 & $38^{2} 25^{\circ} \mathrm{N}$ & $139^{\circ} 15^{\prime} \mathrm{E}$ & 1* & $\begin{array}{l}\mathrm{N} 9^{*} \\
\mathrm{~N}^{*} \mathrm{9}^{*}\end{array}$ & $\begin{array}{l}80 \\
20\end{array}$ & $\begin{array}{c}30 \\
14\end{array}$ & $\begin{array}{l}\left(34^{\circ} \mathrm{El}\right. \\
\left(160^{\circ} \mathrm{E}\right)\end{array}$ & $\begin{array}{l}330 \\
660\end{array}$ & $\begin{array}{c}\text { Reserver } \\
\text { t main fault } \\
\text { Reverse } \\
\text { (subsidiary fautt) }\end{array}$ & $\begin{array}{l}\text { ABE } \\
\text { SATAKE and } A B E, 1983\end{array}$ \\
\hline 5 & 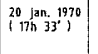 & 7 & $42^{2} 29^{\prime} \mathrm{N}$ & $143^{\circ} 02^{\prime} \mathrm{E}$ & 25 & N $300^{\circ}$ & & & $24^{\circ} \mathrm{NE}$ & & $\begin{array}{l}\text { Reverse } \\
\text { vith hetfl-lateral } \\
\text { strike-slip tomp. }\end{array}$ & $\begin{array}{l}\text { MORIYA, } 1972 \\
\text { CHAPMAN and SOLOMON, } \\
\text {, } 1976 \text {, }\end{array}$ \\
\hline 6 & 21 jan. 1970. & 6.7 & $42.23 \times \mathrm{N}$ & $143^{\circ} 08^{\prime} \mathrm{E}$ & 50 & N-S & & & $80^{\circ} \mathrm{W}$ & & Reverse & $\begin{array}{l}\text { MORIYA. } 1972 \\
\text { TAKANAM1 et al., } 1978\end{array}$ \\
\hline 7 & $\begin{array}{l}31 \text { oct. } 9976 \\
\left(21 \mathrm{ln} 30^{\prime}\right)\end{array}$ & 5.0 & $42^{\circ} 22^{\prime} \mathrm{N}$ & $162^{\circ} 57^{\circ} \mathrm{E}$ & 54 & NW-SE & & & $80^{\circ} \varepsilon$ & & Normal. & TAKANAMI et al,, 1978 \\
\hline 8 & 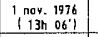 & 4.7 & $42^{2} 20^{\circ} \mathrm{N}$ & $142^{\circ} 56^{\prime} \mathrm{E}$ & 53 & NW-SE & & & $55^{\circ} \mathrm{E}$ & & Normal & TAKANAMI ef at, 1978 \\
\hline 9 & $\begin{array}{c}13 \text { jan.1979 } \\
\left.\text { (in } 377^{7}\right)\end{array}$ & 4.2 & $42^{\circ} 311^{\circ} \mathrm{N}$ & $141^{\prime} 5 z^{\prime} \mathrm{E}$ & $2 t$ & N 311 & & & $50^{\circ} \mathrm{E}$ & & $\begin{array}{l}\text { Left-lateral } \\
\text { strike-slipg }\end{array}$ & TAKANAMI, 1980 \\
\hline 10 & 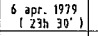 & 3.3 & $36.44 \mathrm{~N}$ & $137^{\circ} 49^{\circ} \mathrm{E}$ & $15^{\circ}$ & & & & & & Strike-slip & FUKAO and YAMAOKA,1983 \\
\hline 11 & 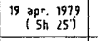 & 2.6 & $36-31 \mathrm{~N}$ & $137^{\circ} 32^{\prime} \mathrm{E}$ & 1.3 & & & & & & Strike-sup & FUKAO and YAMAOKA, 1983 \\
\hline 12 & $\begin{array}{l}16 \text { nov. } 1979 \\
15 h^{5} 57^{\prime} 1\end{array}$ & 4.3 & $3714 \% \mathrm{~N}$ & $138^{\circ} 03^{\prime} \mathrm{E}$ & -29 & N-S & & & & & $\begin{array}{l}\text { Reverse } \\
\text { vith strike-slip } \\
\text { component }\end{array}$ & FUKAO and YAMAOKA, 1983 \\
\hline 13 & 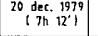 & 2.6 & $36^{\circ} 44^{\prime} \mathrm{N}$ & $138^{\circ} 08^{\prime} \mathrm{E}$ & 5.5 & & & & & & Strike-slip & FUKAO and YAMAOKA, 1983 \\
\hline u & $\begin{array}{c}20 \text { feb. } 1980 \\
\mid 9 h \quad 13^{4} \\
\end{array}$ & 3.3 & $36^{\circ} 50^{\circ} \mathrm{N}$ & $137^{\circ} 30^{\circ} \mathrm{E}$ & 7.3 & & & & & & Strike-slip & FUKAO and YAMAOEKA, 1983 \\
\hline 15 & $\begin{array}{l}9 \text { (Jut. } 1989 \\
\text { tion } 190^{\circ} \\
\end{array}$ & 3.9 & $39^{\circ} 44^{\prime} \mathrm{N}$ & $143^{\circ} 49^{\prime} \mathrm{E}$ & 10 & ENE-WSW & & & & & Reverise & $\begin{array}{c}\text { OBS Ilvision Earthouake } \\
\text { Research lnst., } 1983\end{array}$ \\
\hline 16 & $\begin{array}{r}9 \text { jut. } 1981 \\
\left(10 \mathrm{~h} 28^{\prime}\right) \\
\end{array}$ & 4.3 & $39^{\circ} 49^{\circ} \mathrm{N}$ & $163^{\circ} 43^{\prime} \mathrm{E}$ & 10 & NE-SW & & & & & Reverse & $\begin{array}{l}\text { oes Divisison Ear hhquake } \\
\text { Research Inst., 19893 }\end{array}$ \\
\hline 77 & 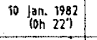 & 4.1 & $37^{1} 18^{\circ} \mathrm{N}$ & $138^{\circ} 43^{\prime} \mathrm{E}$ & 1* & N $5^{\circ}$ & 10 & 4 & $85^{\circ} \mathrm{W}$ & 25 & Reverse & MIZOUE et at.. 1982 \\
\hline 18 & 26 may 1993 & 7.7 & $40^{\circ} 24^{\circ} \mathrm{N}$ & $139^{\circ} 06^{\prime} \mathrm{E}$ & 14 & N-S & $\begin{array}{l}40 \\
60\end{array}$ & $\begin{array}{l}70 \\
30\end{array}$ & $\begin{array}{l}40^{\circ} \mathrm{E} \\
25^{\circ} \mathrm{E}\end{array}$ & $\begin{array}{r}760 \\
300 \\
54\end{array}$ & 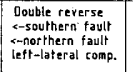 & $\begin{array}{l}\text { AlDA, } 1994 \\
\text { HATOLI, } 1984 \\
\text { ISHIKAWA et al, } 1984\end{array}$ \\
\hline
\end{tabular}

TABLE I. - List of crustal earthquakes located on figure 8 with their parameters.

M : magnitude ; Depth : in km ; F-Strike : strike of the fault plane ; F-Lg : length of the fault plane in $\mathrm{km} ; \mathrm{F}$-Wd : width of the fault plane in $\mathrm{km}$; F-Dip : dip of the fault ; F-D-Sl : dip-slip of the fault in $\mathrm{cm}$.

TABL. I. - Liste des séismes crustaux représentés sur la figure 8 avec leurs différents paramètres.

M : magnitude ; Depth : profondeur en $\mathrm{km} ; \mathrm{F}$-Strike : orientation du plan de faille; F-Lg : longueur du plan de faille en $\mathrm{km} ; \mathrm{F}-\mathrm{Wd}$ : largeur du plan de faille en $\mathrm{km}$; F-Dip : pendage de la faille ; F-D-S1 : projection du rejet net de la faille en $\mathrm{cm}$.

Bull. Soc. géol. Fr., 1987, no 3 (earthquakes $\mathrm{n}^{\circ} 7$ and 8 on figure 7 and 8). Most of them correspond to left-lateral strike-slip faulting [Takanami, 1976], compatible with an E-W to ENE-WSW compression along the southwestern coast of Hokkaido and presumably also near Kushiro. This complexity may be due to the contortion of the subducting Pacific plate at the « Hokkaido corner » [Stauder and Mualchin, 1976].

The earthquakes occurring inside the upper plate along the frontal zone of the forearc probably denote the effect of the active oceanic faults passing below the margin.

\section{V. - Discussion AND CONCLUSION.}

We can observe that the tectonic regime of the arc is roughly the same from the back-arc to the forearc at least since Middle Miocene.

It has been demonstrated that the eastern margin of the Japan Sea was a right-lateral strike-slip margin from Eocene to Lower Miocene [Lallemand and Jolivet, 1986] (fig. 2) with simultaneous right-lateral relative motion between North-American and Eurasian plates along the Hidaka shear zone [Jolivet and Miyashita, 1985]. The small basins on the Japan Sea margin were initiated at this time as subordinate pull-aparts along a zone of weakness. Subsequently, a second opening phase took place and these subordinate pull-aparts opened like graben-basins controled by N-S normal faults during Middle Miocene. This period coincided with the WNW-ESE extension in the arc described by Nakamura and Uyeda [1980] and also with the subsidence of the forearc [Von Huene et al., 1982]. Finally, the N-S ancient normal faults of the Japan Sea margin were rejuvenated during the last 1 or $2 \mathrm{Ma}$ BP into reverse faults which sometimes evolved into thrusts [Lallemand et al., 1985] and simultaneously with this occurred the recent uplift of the forearc region.

What is at the origin of the present tectonic regime all over the arc? As we indicated in the introduction, there is three possibilities each depending on relative motions and mechanical interactions between plates.

1) The location of the Japanese archipelago at the edge of the Asian mainland favours intracontinental extensional or strike-slip tectonics because of the relative free oceanic side (see the propagating extrusion tectonics in Asia [Tapponnier et al., 1982]). It was the case during Cretaceous and Paleogene times, but now the tectonic regime is clearly compressional in an E-W direction.

2) The Japanese islands are located at the junction of two continental and two oceanic plates. If we consider that the boundary between the Amurian and the Okhotsk plates runs along the eastern margin of the Japan Sea and extends southward along the Itoigawa-Shizuoka tectonic line, we have some difficulties to explain first the tectonic regime of the forearc because of the Okhotsk plate configuration ; and second, according to Zonenshain and Savostin [1981], the counter-clockwise rotation of the Amurian plate relative to the Eurasian plate around a pole located on the northern Amur-Eurasia boundary is incompatible with an eastward movement of the Amurian plate relative to the Okhotsk plate as Tamaki and Honza [1985] emphasized. 


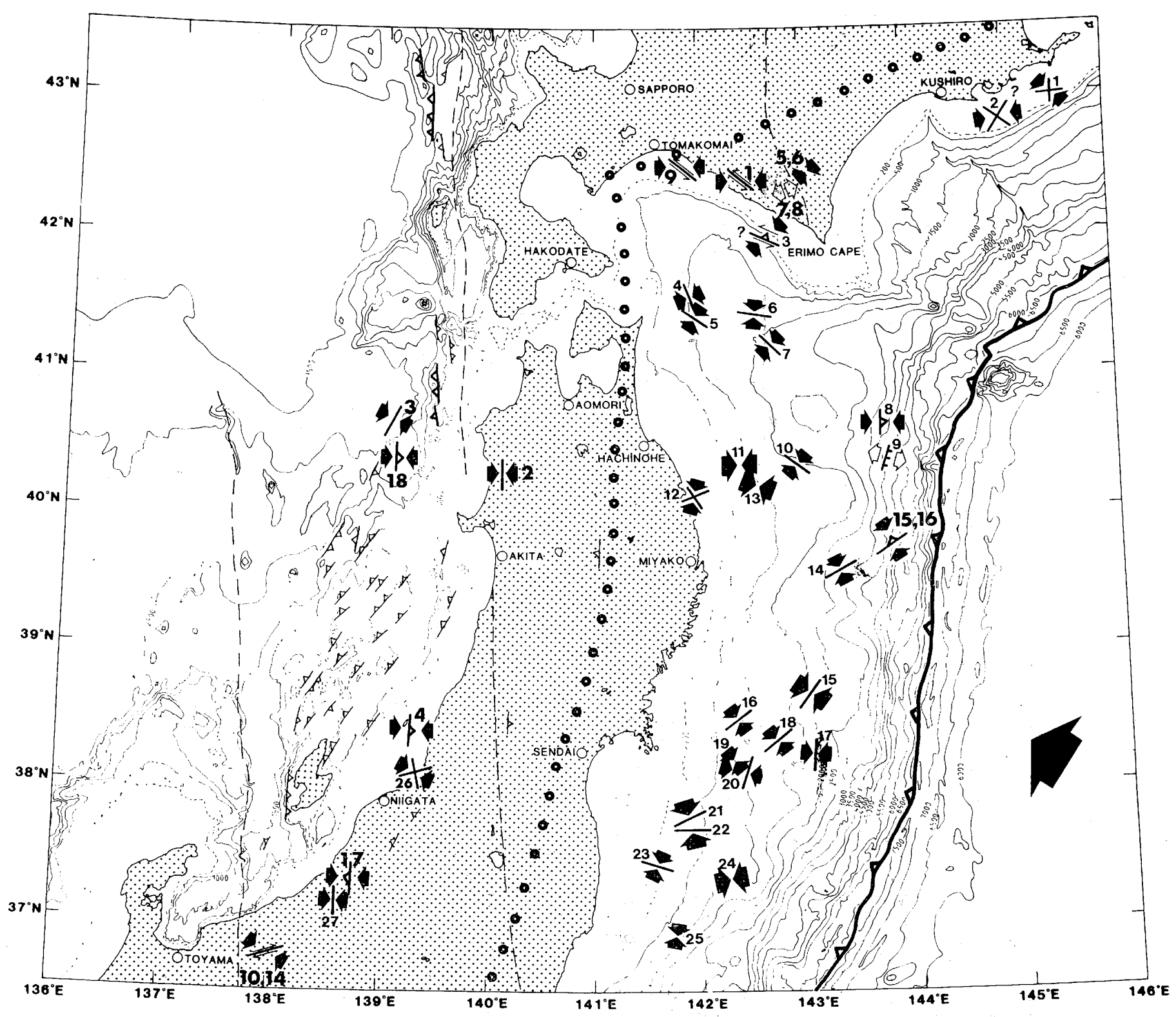

FIG. 8. - Interpretation, in terms of faulting type and maximum horizontal stress field, of earthquakes in addition to some faults recognized by Tamaki and Honza [1985], Lallemand et al. [1985] or the Research Group for Active Faults [1980]. Circles outline the Quaternary volcanic front. The main tectonic lines are represented in dotted lines. Thick numbers refer to the earthquakes listed in table I, whereas thin numbers correspond to earthquakes from 1973 to 1981, deduced from the Japan Meteorological Agency Reports, which date of occurrence follows : 1- 14.06.78 [JMA, 1982] ; 2- 14.07.80 [JMA, 1984] ; 3- 15.03.76 [JMA, 1980] ; 4- 18.02.77. [JMA, 1981] ; 5-24.03.81 (M = 4.9) [JMA, 1985]; 6- 18.06.74 [JMA, 1978] ; 7-14.08.74 [JMA, 1978] ; 8- 12 and 15.10.74 [JMA, 1978] ; 9-20.02.79 [JMA, 1983] ; 10- 10.09.75 [JMA, 1979] ; 11- 10.03 (M = 5.0), $14.04(\mathrm{M}=5.1)$ and 15.10.81 $(\mathrm{M}=6.0)$ [JMA, 1985] ; 12-04.09.74 [JMA, 1978] ; 13- 06.07.73, 25.04.77 and 17.03.80 [JMA, 1977, 1981 and 1984] ; 14- 10.09.73 [JMA, 1977] ; 15-16.08.79 and 19.01.81 (M = 7.0) [JMA, 1983 and 1985] ; 16- 06.06.73 [JMA, 1977] ; 17- 23.01.81 (M = 6.6) [JMA, 1985] ; 18- 04.06.76 [JMA, 1980] ; 19- 12.06.78 [JMA, 1982] ; 20- 08.11.76 [JMA, 1980] ; 21-05.05.74 [JMA, 1978]; 22-08.04 and 13.04.75 [JMA 1979] ; 23-07.08.76 [JMA, 1980] ; 24- 24.08.73 and 04.05.75 [JMA, 1977 and 1979]; 25- 21.03.74 [JMA, 1978]; 26-17.08.79 [JMA, 1983] ; 27-06. $02.81(\mathrm{M}=4.4)$ [JMA, 1985].

FIG. 8. - Interprétation, en terme de fracturation et de contrainte horizontale maximum, des séismes ainsi que quelques failles reconnues par Tamaki et Honza [1985], Lallemand et al. [1985] ou The Research Group for Active Faults [1980]. Les cercles délimitent le front du volcanisme quaternaire. Les lignes tectoniques principales sont représentées en pointillés. Les chiffres en traits gras correspondent aux séismes listés dans le tableau I, tandis que ceux en traits fins correspondent aux séismes de 1973 à 1981 déduits des rapports du Japan Meteorological Agency. 
An alternative explanation may be the continuation of the westward movement of the Okhotsk plate relative to the Amurian plate, but there is not sufficient data, at present, to support this hypothesis, except the focal mechanism of the Sept. 5, 1971 earthquake which occurred in the southwestern part of Sakhalin Island $(M=7.3)$ showing WSWENE compression [Savostin et al., 1983].

3) Considering the high subduction rate of the Pacific plate under the NE Japan $(10 \mathrm{~cm} / \mathrm{year})$, the low dip of the slab and the curvature between the Japan and Kuril trenches, it is possible to relate the tectonic regime all over the arc since the Middle Miocene to the subduction process. One possible interpretation of the particular eastern margin of Japan Sea activity may be the past tectonic history with the creation of a zone of weakness where the continental lithosphere preferentially accomodates the deformation.

Finally, from Eocene to Lower Miocene, the rightlateral movement between the North-America and the Eurasia plates governed the tectonics, at least for the first stage of opening of the Japan Sea [Lallemand and Jolivet, 1986]. The reactivation of the Pacific plate subduction occurred sometime during Oligocene [von Huene et al., 1982]. The tripling of the Pacific plate motion at $25 \mathrm{Ma}$ [Van Andel, 1974] may be at the origin of the back-arc spreading (second opening) in the Japan Sea associated with E-W extension, i.e. Mariana-type mode of subduction of Uyeda [1982]. This mode must have changed from Mariana-type to Chilean-type during Pliocene [Sugi et al., 1983] for some reason. Was it due to a detachment of the Pacific slab [Kanamori, 1977 ; Niitsuma, 1978] as suggested by the seismic gap under the Japan Sea if we extrapolate the slab or to the change of the Pacific plate motion at $5 \mathrm{Ma}$ as stated by Cox and Engebretson [1985] ?

Acknowledgements. - The authors are greatly indebted to doctors H. Shimamura (Laboratory for Ocean Bottom Seismology, Sapporo) and Y. Motoya (Research Center for Earthquake Prediction, Sapporo) for their help to obtain earthquakes data. Professor Kobayashi, director of the laboratory of Ocean Floor Geotectonics, Ocean Research Institute, Tokyo and co-chief scientist of the Leg 3 of KAIKO cruise received kindly S. Lallemand in his laboratory during 15 months. We thank also Drs B. Biju-Duval and J. F. Stephan for their critical review. The work has been supported by the French Ministry of Foreign Affairs, CNRS and IFREMER. We thank Professor A. J. Smith, who reviewed the english.

\section{References}

Japan Meteorological Agency (1984). - List of nodal plane solutions for earthquakes occurring in 1980. - The Seismol. Bull. of the JMA for Dec. 1983, pp. 143-144.

ABE K. (1975). - Re-examination of the fault model for the Niigata earthquake of 1964. - J. Phys. Earth, 23, pp. 349-366.

ArDA I. (1984). - A source model of the tsunami accompanying the 1983 Nihonkai-Chubu earthquake. - Bull. Earthq. Res. Inst., Univ. Tokyo, 59, pp. 93-104. — (in Japanese with English abstract)

Cadet J.-P., Kobayashi K., Aưbouin J., Boulègúe J., Dưbors J., Von Hưene R., Jolivet L., Kanazawa T., Kasahara J., Kolzumi K., Lallemand S., Nakamura Y., Paútot G., Sưehiro K., Tani S., TokuYama H. \& Yamazaki T. (1985) - De la fosse du Japon à la fosse des Kouriles : premiers résultats de la campagne océanographique franco-japonaise Kaïko (Leg III). - C. R. Acad. Sci., Paris, II, 301, 5, pp. 287296.

Cadet J. P., Kobayashi K., Aưbouin J., Boulègue J., Deplứ C., Dưbois J., Von Huene R., Jolivet L., Kanazawa T., Kasahara J., Kolzumi K., Lallemand S., Nakamưra Y., Pautot G., Suyehiro K., Tani S., Tokuyama H. \& YamaZAKI T. (1987). - The Japan Trench and its juncture with the Kuril Trench. Cruise Results of the Kaïko project, Leg 3. - Earth Planet. Sci. Lett., sp. issue (in press).

Chapman M. E. \& Solomon S. C. (1976). - North American-Eurasian plate boundary in northeast Asia. - J. Geophys. Res., 81, 5, pp. 921-930.

Cox A. \& Engebretson D. (1985). - Change in motion of the Pacific plate at 5 Ma BP. - Nature, 313, pp. 472-474.

Fúao Y. \& Furúmoto M. (1975). - Mechanism of large earthquakes along the eastern margin of the Japan Sea. - Tectonophysics, 25, pp. 247-266.

FúKAO Y. \& YAMAOKA (1983). - Stress estimate for the highest mountain system in Japan. - Tectontics, 2, 5, pp. 453-471.

Hasegawa A., Umino N., Takagi A., Suzuki S., Motoya Y., KameYa S., TanaKa K. \& Sawada Y. (1983). - Spatial distribution of earthquakes beneath Hokkaido and northern
Honshu, Japan. - Zisin (J. Seismol. Soc. Japan), 36, 2 , pp. 129-150. - (in Japanese with English abstract).

HATORI T. (1984). - The tsunami associated with an aftershock of the 1983 Nihonkai-Chubu earthquake, and the source mechanism of the main tsunami. - Bull. Earthq. Res. Inst., Univ. Tokyo, 59, pp. 105-113. - (in Japanese with English abstract).

ICHIKAWA M. (1971). - Reanalyses of mechanism of earthquakes which occurred in and near Japan, and statistical studies on the nodal plane solutions obtained, 1926-1968. - Geophys. Mag., 35, 3, pp. 207-274.

IsHIKawa Y. et al. (1984). - Process of the Nihonkai-Chubu earthquake in 1983. - Marine Science monthly, 6, 1, pp. 11-17. - (in Japanese)

Ishiwada Y., Ikebe Y., Ogawa K. \& Onitsuka T. (1977), - A consideration on the scheme of sedimentary basins of northeast Japan. - Memorial Volume Prof. K. HUZIOKA, Univ. Akita, pp. 1-17.

Japan Meteorological Agency (1977). - List of nodal plane solutions for earthquakes occurring in 1973. - The Seismol. Bull. of the JMA for Dec. 1976, pp. 60-61.

Japan Meteorological Agency (1978). - List of nodal plane solutions for earthquakes occurring in 1974. - The Seismol. Bull. of the JMA for Dec. 1977, pp. 71-72.

Japan Meteorological Agency (1979). - List of nodal plane solutions for earthquakes occurring in 1975. - The Seismol. Bull. of the JMA for Dec. 1978, p. 108.

Japan Meteorological Agency (1980). - List of nodal plane solutions for earthquakes occurring in 1976. — The Seismol. Bull. of the JMA for Dec. 1979, pp. 92-93.

Japan Meteorological Agency (1981). - List of nodal plane solutions for earthquakes occurring in 1977. - The Seismol. Bull. of the JMA for Dec. 1980, pp. 91-92.

Japan Meteorological Agency (1982). - List of nodal plane solutions for earthquakes occurring in 1978. - The Seismol. Bull. of the JMA for Dec. 1981, pp. 69-70.

Japan Meteorological Agency (1983). - List of nodal plane solutions for earthquakes occurring in 1979. - The Seismol. Bull. of the JMA for Dec. 1982, p. 230.

Bull. Soc. géol. Fr., 1987 n 3 
Japan Meteorological Agency (1985). - List of nodal plane solutions for earthquakes occurring in 1981. - The Seismol. Bull. of the JMA for Dec. 1984, pp. 189-190.

Jolivet L. \& MryAshita S. (1985). - The Hidaka shear zone (Hokkaido, Japan) : genesis during a right-lateral strike-slip movement. - Tectonics, 4, 3, pp. 289-302.

KANAMORI H. (1977). — Seismic and aseismic slip along subduction zones and their tectonic implications. In : TALWANI M. \& PitMan W. C. III, Eds., Island arcs, deep-sea trenches and back-arc basins. - Maurice Ewing series 1, Amer. Geophys. Un., pp. 163-174.

Kobayashi Y. (1984). - Time and space distribution of large earthquakes which occurred at place boundaries. - Marine Science monthly, 6, 1 (in Japanese), pp. 9-10.

Lallemand S., Cadet J.-P. \& Jolivet L. (1986). - Mécanisme de tectogenèse à la base du mur interne de la fosse du Japon (au large de Sanriku, Japon NE) : rejeu des failles océaniques sous la marge. - C. R. Acad. Sci., Paris, II, 302, 6, pp. 319-324.

Lallemand S. \& Jolivet L. (1986). - The Japan Sea : a pull apart basin? - Earth Planet. Sci. Lett., 76, pp. 375-389.

Lallemand S., Okada H., Otsưka K. \& Labeyrie L. (1985). - Tectonique en compression sur la marge est de la mer du Japon : mise en évidence de chevauchements à vergence orientale. - C. R. Acad. Sci., Paris, II, 301, 3, pp. 201-206.

Lee G., Besse J., Courtillot V. \& Montigny R. (1987). - Eastern Asia in the Cretaceous : new paleomagnetic data from south Korea and a new look at Chinese and Japanese data. $-J$. Geophys. Res. - (in press).

Lehner P., Doust H., Bakker G., Allenbach P. \& Gueneau J. (1983). - Active margins. Part 1 : Japan Trench, profile P-984. In : BALly A. W. Ed., Seismic expression of structural styles, a picture and work atlas. - $A A P G$ studies in Geology 15,3

MitANI K. (1978). - Changing of the Tertiary sedimentary basins in the western flank of the axial belt of Hokkaido-bearing a significance of the Sunagawa lowland to Umaoi Hilly belt. - Assoc. Geol. Coll. Jap., Mon. 21, pp. 127-137.

Mizoú M., Yokata T. \& Nakamura I. (1982). - High-angle reverse faultings in the interaxial zone of active folds in the inner belt of northeast Japan. - Bull. Earthq. Res. Inst., Univ. Tokyo, 57, pp. 359-377.

Mogi A. (1981). - Active tectonic zone along the Japan Sea coast of northern Honshu, the Fossa Magna and the Tokai-Izu region, and the recent seismic activity in the Izu region. - Bull. Earthq. Res. Inst., Univ. Tokyo, 56, pp. 691-711. - (in Japanese with English abstract).

Moore G. W. \& FuJIOKA K. (1980). - Age and origin of dacite boulder conglomerate anomalously near the Japan trench. In : Init. Rep. DSDP, 56-57. - pp. 1083-1088.

MORIYA T. (1972). - Aftershock activity of the Hidaka Mountains earthquake of January 21, 1970. - Zisin (J. Seismol. Soc. Japan), 24, 2, pp. 287-297. - (in Japanese with English abstract).

NAKamura K. (1983). - Possible nascent trench along the eastern Japan Sea as the convergent boundary between Eurasian and North-American plates. - Bull. Earthq. Res. Inst., Univ. Tokyo, 58, pp. 721-732. - (in Japanese with English abstract)

NAKAMURA K. (1984). - Hypothesis of the convergent margins of the plates along the Japan Sea and Fossa Magna. - Marine Science monthly, 6, 1, pp. 25-28. - (in Japanese).

NAKAMURA K. \& UYEDA S. (1980). - Stress gradient in arc - back-arc regions and plate subduction. - $J$. Geophys. Res., 85, B 11, pp. 6419-6428.

Nirtsuma N. (1978). - Magnetic stratigraphy of the Japanese Neogene and the development of the island arc of Japan. - J. Phys. Earth, 26, Suppl., pp. 367-378.

Ocean Bottom Seismology Division, Earthquake Research Institute, Univ. Tokyo (1983). - Focal mechanism of the earthquake swarm on July 7, 1981 occurring on the inner slope of Japan trench (depth 3 000-4 000 m). - Rep. Coord. Comm. Earthq. Pred., 29, Febr. 1983, Geogr. Survey Inst., Min. Constr., Japan, pp. 20-21. - (in Japanese).

OKada H., Lallemand S., OTSUKA K. \& LabeYRIE L. (1985). - Submarine geologic structure of the eastern margin of the Japan Sea with special reference to the nascent trench problem. -
Geosc. Rep. of Shizuoka Univ., 11, pp. 119-133. - (in Japanese with English abstract).

OTsUKi K. \& EHIRo M. (1978). - Major strike-slip faults and their bearing on spreading in the Japan Sea. - J. Phys. Earth, 26, Suppl. pp. 537-555.

Otsuki K., Nakata T. \& Imaizumi T. (1979). - Quaternary crustal movements and block model in the southeastern region of the northeast Japan. - Earth Science (Chikyu Kagaku), 31, pp. 1-14. - Abstract in : Nat. Rep. of the Geodynamics Project, Japan, 7, II, pp. 36-37.

Satake K. \& Abe K. (1983). - A fault model for the Niigata, Japan, earthquake of June 16, 1964. - J. Phys. Earth, 31, pp. 217-223.

Savostin L., Zonenshain L. \& Baranov B. (1983). - Geology and plate tectonics of the Sea of Okhotsk. In : Hilde T. W. C. \& UYEDA S. Eds., Geodynamics of the western-Pacific Indonesian regions. - Geodynamics series, 11, pp. 189-221.

Seno T. (1983). - A consideration on the "Japan Sea subduction hypothesis ». Seismic slip vectors along the Japan trench. - Zisin (J. Seismol. Soc. Jpn), 36, pp. 270-273. - (in Japanese).

Seno T. (1985). - Is northern Honshu a microplate ? - Tectonophysics, 115 , pp. 177-196.

STAUdDeR W. \& MUALCHIN L. (1976). - Fault motion in the larger earthquakes of the Kurile-Kamchatka Arc and the KurileHokkaido Corner. - J. Geophys. Res., 81, pp. 297-308.

SUGi N., CHINZEI K. \& UYEDA S. (1983). - Vertical crustal movements of northeast Japan since Middle Miocene. $I n$ : HILdE T. W. C. \& UyedA S. Eds., Geodynamics of the western PacificIndonesian region. - Geodynamics series, 11, pp. 317-329.

Takahashi M. (1983). - Space-time distribution of late Mesozoic to early Cethozoic magmatism in East Asia and its tectonic implications. In : HASHIMOTO M. \& UYEDA S. Eds., Accretion tectonics in the circum-Pacific region. - Terrapub, Tokyo, pp. 69-88.

TAKANAMI T. (1976). - Recent seismic activity of microearthquakes in and around the southern part of Hidaka Range, Hokkaido and some related problems. - Symp. stbterranean structure in and around Hokkaido and its tectoric implications. - Sept., pp. 84-97.

TAKANAMI T. (1980). - On the earthquake on Jan. 13, 1979 off Mukawa, southern Hokkaido. - Zisin (J. Seismol. Soc. Japan), 33, 2, pp. 169-185. - (in Japanese with English abstract).

Takanami T., Maeda I. \& Motoya Y. (1978). - On the earthquake on Oct. 31, 1976 in the Hidaka Range, southern Hokkaido. - Zisin (J. Seismol. Soc. Japan), 31, 2, pp. 321-333. - (in Japanese with English abstract).

TAKeUCHI A. (1983). - On the episodic vicissitude of tectonic stressfield of the Cenozoic northeast Honshu arc, Japan. - OJI Internat. Sem. The formation of ocedn margins, nov. 21-23, 1983, - Tokyo, pp. 20-21.

TAMAKI K. \& Honza E. (1985). - Incipient subduction and obduction along the eastern margin of the Japan Sea. - Tectonophysics, 119 , pp. 381-406.

TAPPONNIER P. et al. (1982). - Propagating extrusion tectonics in Asia : new insights from simple experiments with plasticine. - Geology, 10, pp. 611-616.

The Research Group for Active Faults of Japan (1980). - Active faults in and around Japan : the distribution and the degree of activity. - J. Nat. Disaster Sci., 2, 2, pp. 61-99.

The Research Group for Active Faults (1980). - Active faults in and around Japan. - Map. scale 1/2000000. Univ. Tokyo Press.

UYEDA S. (1982). - Subduction zones : an introduction to comparative subductology. - Tectonophysics, 81, pp. 133-159.

VAN ANDEL T. H. (1974). - Cenozoic migration of the Pacific plate northward shift of the axis of deposition and paleobathymetry of the central equatorial Pacific. - Geology, 2, pp. 507-510.

Von Huene R., Langseth M., Nasu N. \& Okada H. (1982). - A summary of Cenozoic tectonic history along the IPOD Japan Trench transect. - Geol. Soc. Am. Bull., 93, pp. 829-846.

Von HuENe R. (1986). - To accrete or not accrete, that is the question. - Geol. Rundsch., 75, 1, pp. 1-15.

Zonenshain L. P. \& Savostin L. A. (1981). - Geodynamics of the Baikal rift zone and plate tectonics of Asia. - Tectonophysics, 76 , pp. 1-45. 